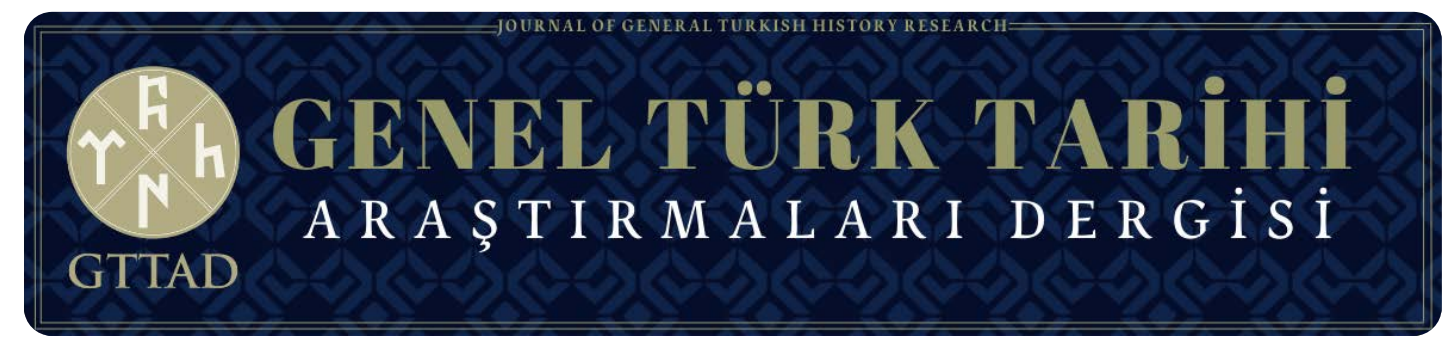

Cilt/Volume 4, Sayı/Issue 7, Ocak/January 2022, ss. 69-78.

Geliş Tarihi-Received Date: 11.08.2021 Kabul Tarihi-Accepted Date: 02.11.2021

\author{
ARAŞTIRMA MAKALESİ - RESEARCH ARTICLE \\ İLK DÖNEM İLHANLI-ALTIN ORDA REKABETINIIN SEBEPLERİ HAKKINDA BİR \\ DEĞERLENDİRME
}

DIDIBRAHIM GÜNEŞ*

doi $10.53718 /$ gttad.981644

\begin{abstract}
ÖZ
$\mathrm{Bu}$ çalışmada, İlhanlı-Altın Orda devletleri arasındaki düşmanlığın ortaya çıkmasına neden teşkil eden gelişmelerle birlikte, kaynaklar tarafindan rivayet edilen kayıtların analizi yapılacaktır.13. ve 14. asırda İran, Azerbaycan, Horasan, el-Cezire ve Irak'a hâkim olan İlhanlılar Devleti ile Rus, Bulgar ve Kıpçak topraklarına hâkim Altın Orda Devleti arasında uzun süren bir düşmanlık yaşanmıştır. Bu düşmanlığın ortaya çıkmasına birçok faktörün sebep olduğu bilinmekle birlikte Büyük Moğol İmparatorluğu'nun batı topraklarının Altın Orda’ya bırakılması ve Hülegü’nün 1258 yılında Bağdat'ın zaptı sırasında Halife’ye kötü davranıp onu katlettirmesi bu faktörlerin başında gelmektedir. Nitekim İlhanlılar, kuruluş devrinde Altın Orda'nın hissesine düştüğü bilinen Azerbaycan topraklarını kendilerine bağlamışlardı. Ayrıca Berke Han, Halife'nin başına gelenlerden dolayı Hülegü’yü şiddetle eleştirirken bu hususta kendisini bilgilendirmediği için tehditlerde bulunması, iki devlet arasında uzun zaman sürecek bir düşmanlığa sebep olmuştur.

İlhanlılar ile Altın Orda arasındaki rekabet birçok minvalde devam etmiştir. Buna göre hem Alamut'un hem de Bağdat'ın ele geçirilmesi sırasında ganimetlerden bir kısmının Cengiz Han yasasına göre Altın Orda'nın hakkı olmasına rağmen İlhanlılar bunu vermeye yanaşmamıştır. Bu da iki taraf arasında kopuşun başlamasına sebep olmuş ve daha sonra bu kopuş yerini düşmanlığa bırakmıştır. Özellikle Bağdat'ın zaptından sonra başlayan gerginlik, İlhanlıların başkent olarak ilk başta Meraga, ardından da Tebriz’i seçmeleri Altın Orda'nın İlhanlılara savaş açmasıyla neticelenmiştir. Kendi hakkı olduğunu iddia etmelerine rağmen Kafkasya ve Azerbaycan topraklarının İlhanlılar tarafından ilhak edilmesi, Altın Orda cephesindeki düşmanlığın sebepleri arasında gösterilebilir. Öyle ki Azerbaycan'ın Moğol ordularının atlarına uygun yaşam koşullarına sahip olması, her iki tarafın ne pahasına olursa olsun buradan vazgeçmeme gibi bir siyaseti sürdürmelerine sebep olmuştur. Özellikle Nahcivan, Meraga, Mugan, Tebriz ve Sultaniyye gibi şehir veya bölgeler göçebelerin birçok ihtiyacını giderdiğinden, burası atlı göçebe sistemine göre inşa edilmiş İlhanlı ve Altın Orda orduları için birer cazibe alanı hâline gelmiştir. Nitekim geniş meralar, atların yem ihtiyacını karşılarken askerlerin de yaşamlarını idame ettirmelerine yarayan geniş su ve av sahalarına sahiptiler. Bundan olacak ki İlhanlı hükümdarları ve askerleri, savaşların olmadığı dönemlerde zamanlarının çoğunu Kafkasya ve Azerbaycan’daki yaylak ve kışlaklarda geçirmişlerdir.

Öte yandan Memlûklerin Altın Orda Devleti’ni daima İlhanlılara karşı tahrik etmeleri de taraflar arasında düşmanlığın başka bir yönünü oluşturmaktadır. Özellikle Memlûk Sultanı Baybars, Berke Han’ı Hülegü’ye karşı dinî sebeplerden dolayı savaşmaya ikna emek için bir dizi diplomatik temasta bulunmuştur. Nitekim İ́slam'a göre Müslümanlığa saldıran herkese karşı cihat yapmak gerekiyordu ve Sultan Baybars da Berke Han'dan bu uğurda mücadele etmesini istiyordu. Fakat Sultan Baybars'ın buradaki yegâne amacı, iki Moğol devleti arasında bir düşmanlık meydana getirterek Haçlılara ve İlhanlılara karşı yaptığı savaşlarda yükünü hafifletmekti. Neticede bahsedilen tüm sebepler iki devlet arasında kalıcı bir düşmanlığın ortaya çıkmasına sebep olmuş ve bu da uzun süren bir çatışmalar silsilesine sebep olmuştur.
\end{abstract}

Anahtar Kelimeler: İlhanlı Devleti, Altın Orda Devleti, Hülegü, Abâkâ, Berke.

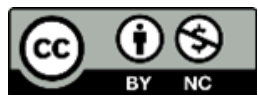

*Dr., TÜRKIYE, E-Posta: ibrahimgn02@gmail.com, ORCID ID: 0000-0002-2080-8870 


\title{
İLK DÖNEM İLHANLI-ALTIN ORDA REKABETININ SEBEPLERİ HAKKINDA BİR DEĞERLENDİRME
}

\section{AN EVALUATION ON THE CAUSES OF THE FIRST PERIOD ILKHANID-GOLDEN HORDE OPPOSITION}

\begin{abstract}
In this study, the developments that led to the emergence of enmity between the Ilkhanid-Golden Horde states and the records narrated by the sources will be analyzed. In the $13^{\text {th }}$ and $14^{\text {th }}$ centuries, there was hostility between the Ilkhanate, who dominated Iran, Azerbaijan, Khorasan, al-Jazeera and Iraq, and the Golden Horde State, which dominated the Russian, Bulgarian and Kipchak lands. Although many factors seem to have contributed to the emergence of this enmity, the western lands of the Great Mongol Empire were left to the Golden Horde and Hulegü mistreated and murdered the Caliph during the seizure of Baghdad in 1258. As a matter of fact, with the establishment of the Ilkhanids, the Azerbaijan lands that were known to belong to the Golden Horde, and Berke Khan, who became a Muslim, severely criticized Hulegu for what had happened to the Caliph, while threatening him because he did not inform him about this issue, caused a long-lasting hostility between the two states will be.
\end{abstract}

The rivalry between the Ilkhanids and the Golden Horde continued in many ways. According to this, during the capture of both Alamut and Baghdad, although some of the spoils were the right of the Golden Horde according to the law of Genghis Khan, the fact that the Ilkhanate did not give this led to the first break between the two sides, and later this break left its place to enmity. The tension that started especially after the conquest of Baghdad, the fact that the Ilkhans chose Meraga and then Tabriz as the capital, resulted in the Golden Horde going to war against the Ilkhanids. It is known that the annexation of the Caucasian and Azerbaijani lands by the Ilkhanate, although they claim that it is their right, is the most important pillar of the events among the reasons for their hostility in the Golden Horde front. The fact that Azerbaijan had living conditions suitable for the horses of the Mongolian armies caused both sides to pursue a policy of not giving up at any cost. Especially since cities or regions such as Nakhchivan, Meraga, Mugan, Tabriz and Sultaniyye met many of the needs of the nomads, they made this place an attraction for the Ilkhanid and Golden Horde armies, which were built according to the horse nomadic system. As a matter of fact, these places had large water and hunting grounds for the soldiers to maintain their lives, while the wide pastures met the feed needs for the horses. It will be that the Ilkhanid rulers and soldiers spent most of their time in the summer pastures and winter quarters in the Caucasus and Azerbaijan during the absence of wars.

On the other hand, the fact that the Mamluks always provoked the Golden Horde against the Ilkhanate would create another aspect of hostility between the parties. Especially the Mamluk Sultan Baybars made a series of diplomatic contacts to persuade Berke Khan to fight against Hulegu for religious reasons. As a matter of fact, Berke Khan was a Muslim and Hülegü, who did not belong to any religion, had obviously done great harm to Muslims both in Baghdad and Syria. It was necessary to make jihad against anyone who attacked Islam, and Sultan Baybars wanted Berke Khan to fight for this cause. However, the sole purpose of Sultan Baybars here was to ease his burden in the wars he waged against the Crusaders and Ilkhanids by creating an enmity between the two Mongol states. As a result, all the reasons mentioned will cause a permanent enmity to emerge between the two states and the enmity will continue with a long-lasting conflict.

Keywords: Ilkhanid State, Gorden Holde State, Hulegu, Abaka, Berke.

\section{GíRiş}

İlhanl1-Altın Orda münasebetleri, akrabalıktan birlikte hareket etmeye, birlikte hareket etmekten anlaşmazlığa, anlaşmazlıktan da çatışmaya doğru bir tarihî seyir izlemektedir. Hülegü zamanında başlayan ve Abâkâ'nın ${ }^{1}$ tahta geçmesiyle daha da derinleşen husumet, iki önemli Moğol devletinin arasını bir daha düzelmeyecek ölçüde bozmuştur. Öyle ki her iki devlet arasındaki anlaşmazlık, müzmin bir hâl alarak İlhanlı Devleti'nin yıkııışına kadar devam etmiştir. Hem İlhanlı hem de Memlûk kaynaklarında iki devlet arasındaki söz konusu husumetin sebeplerinin farklı rivayetlerle ele alınması ve her sebebin de meseleye farklı bir açıdan bakılmasını gerektirmesi, bu hususun gerçek sebeplerini öğrenmede bir hayli zorluk çıkarmaktadır. Nitekim devrin kaynaklarındaki rivayetler her ne kadar birbirini tamamlıyor olarak görülse de rivayetlerin içeriğine daha derinlemesine bakıldığında, bunların çoğu kez birbirlerine zitlık teşkil edecek şekilde olay örgüsüne sahip oldukları anlaşılmaktadır. Esas itibariyle bu tartışmalar, akademik camianın da ilgisine mazhar olmuş ve bu

\footnotetext{
${ }^{1}$ Abâkâ Han hakkında şu çalışmaya bkz. İbrahim Güneş, Abâkâ Han Devrinde İlhanlı Devleti Tarihi (663-680/1265-1282), Muğgla Üniversitesi Sosyal Bilimler Enstitüsü (Yayımlanmamış Doktora Tezi), Muğla 2021.
} 


\section{İBRAHIM GÜNES}

konuda da geniş bir literatür oluşmuştur. ${ }^{2}$ Fakat bu çalışmalarda iki devletin arasındaki çekişmelerin sebeplerinin üzerinde kısa durulduğundan söz konusu meselenin daha etraflıca ele alınması gerekliliğini ortaya çıkarmıştır. Buradaki esas amaç ise iki taraf arasında, özellikle de Hülegü devrinde başlayan ve Abâkâ devrinde daha da artan savaşların nedenleri ile birlikte tarihî seyirlerini ortaya koymak ve en önemlisi bu düşmanlıkta Azerbaycan topraklarının etkisini ortaya çıkarmaktır.

\section{1. İki Kardeş Devlet Arasındaki Kopuşun Başlangıcı}

İlhanlılar ile Altın Orda arasındaki çekişmelere dair kaynaklarda bir yığın rivayet vardır ki burada Hülegü ile Berke arasında Terek Nehri savaşının asıl sebebi telakki edilecek bir öldürülme hadisesi ile başlamak gerekecektir. Hülegü'nün İran seferine giriştiği sırada Mönge Han'ın emri ile tüm Moğol hükümdarlarının askerî destekte bulunduğu bilinmektedir. Bunların içinde Altın Orda hükümdarı Batu'nun askerleri de yer alıyordu. Batu 1256 yılında ölüp yerine Berke ${ }^{3}$ geçince, selefinin siyasetini devam ettirip Bağdat'ın zaptına asker göndermişti. Söz konusu bu sefer sırasında görev alan Altın Orda asilzadelerinden Tutar, Bulugan ve Kulu’nun İlhanlılara karşı düşmanca davrandıkları iddia edilmişti. Bunlardan Bulugan, Berke tarafindan infaz edilmiş, ardından Tutar ve Kulu'nun ani ölümlerini şüpheyle karşılayan Berke ise bunun sorumlusu olarak Hülegü’yü görmüştür. ${ }^{4}$ Ermeni kaynaklarından Kiragos ve Mhithar’a göre Kulu, Bolaka (Bulugan), Tutar, Meğhan ve KataHan bizzat Hülegü tarafından öldürülmüştü. ${ }^{5}$ Geri kalan emir ve askerler ise Berke'nin yanına iltica etmişlerdi. Neticede Tutar'ın öldürülmesi, Berke için bardağı taşıran son damla oldu. Reşîdüddîn ise meseleye açıklık getirmeye çalışarak Berke'nin ağabeyi Batu tarafindan Mönge Han'ın tahta cülusu sırasında Karakurum'a gönderildiği tarihten itibaren Hülegü’den emrivaki isteklerde bulunduğunu yazar. Ayrıca Hülegü’nün ona büyüğü olmasından ötürü ses çıkarmadığını, Tutar, Bulugan ve Kulu arasında yaşanan bir olaydan ve Tutar'ın ölümü üzerine Hülegü ve Berke arasında da düşmanlığın başladığını bildirir. Bu sebeple söz konusu düşmanlık günden güne artmışt1. ${ }^{6}$ Müellif, ayrıca söz konusu vaziyet devam edince Hülegü’nün "gerçi Berke akadır, bana karşı utanma ve insafı olmadı $\breve{l}$, beni tehdit edip kaba bir tarzda hitap ettiği için bundan sonra ondan korkmayacağım” dediğini, Berke ise Hülegü’nün kendisine kızdığını işittiğinde de "O bütün Müslümanların şehirlerini harap etti. İslam padişahlarının hanedanlarının hepsini ortadan kaldırdı. Dost ile düşman arasında ayırım gözetmedi ve Halifeyi aka ve ini ile kengeş etmeden öldürdü. Ĕger ebedi Allah yardımcı olursa, suçsuzların kanını ondan isteyeceğim" şeklinde karşılık verdiğini rivayet eder.

İlhanlı kaynaklarının verdiği bu bilgilerden, Hülegü'nün Altın Orda’nın saldırgan tutumu karşısında soğukkanlılığını koruduğu anlaşılmaktadır. Fakat esas itibari ile iki devlet arasındaki düşmanlık, İlhanlıların Altın Orda'nın hissesine bırakılan birtakım hakları gasp etmesiyle doğrudan ilişkiliydi. Özellikle taraflar arasındaki rekabetin birçok sebebi bulunurken, bunların tümü ile çıkar çatışması çerçevesinde cereyan ettiği görülmektedir. Nitekim İran seferinin ardından Hülegü’nün Cengiz Yasası'na göre fethettiği toprakları diğer Moğol devletleri ile bölüştürmek yerine tümünün tasarrufunu kendi eline almış olmasında, Altın Orda'nın İlhanlılara savaş açmasının önemli bir etken olduğu bilinmektedir. ${ }^{8}$ Özellikle İsmailî kaleleri ile birlikte Bağdat' ın İlhanlılar tarafından zaptı ve onu takip eden el-Cezire ve Suriye seferleri sırasında, muazzam miktarda toprak ve ganimet ele geçirilmişti. Altın Orda hükümdarı Berke de Cengiz Yasası'na göre kendi hakkı olan ganimetten pay olarak Azerbaycan'ın kendilerine bırakılmasını talep etmiştir. Ayrıca öyle anlaşılıyor ki Batu'nun ölümünden sonra (1256) Mönge Han'ın üstündeki Altın Orda baskısının ortadan kalkması ile birlikte Kubilây'a karşı Berke'nin açık bir şekilde Arık Boğa'yı desteklemiş olması, İlhanlıları Altın Orda'ya karşı bir savunma bloğu hâline getirmişti. Bu suretle halifenin öldürülmesi ve ardından Hülegü'nün Altın Orda'nın Azerbaycan ve Kafkaslardaki haklarını gasp etmesi de Berke’yi bir hayli öfkelendirmiş olmalıydı. Aşağıda

\footnotetext{
2 İlhanlı-Altın Orda ilişkileri önemine binaen birçok çalışmada ele alınmıştır. Bkz. Mustafa Kafalı, Altın Orda Hanlığının Kuruluşu ve Yükseliş Devirleri, İstanbul 1976, ilgili yerler; Ahmad Hesamipour Khelejani, Illhanlılar ile Altın Orda Devleti’nin Siyasi ve Sosyal İlişkileri, Ege Üniversitesi Sosyal Bilimler Enstitüsü (Yayımlanmamış Doktora Tezi), İzmir 2013; İlyas Kamalov, Moğolların Kafkasya Politikası, Kaknüs Yayınevi, İstanbul 2003; Meryem Muhammedî, “Avamil Mu’ser der Revabıt İran ve Ordu-yı Zerrin der Devre-i Zamamdarî Hûlâgû ve Abâkâ Han”, Pejuheşname-i Tarih, C. II, S. 4, Zemistan 1386, s. 103-125; Cevad Abbas-Meryem Muhammedî, “Te’sir Hükümethay-yı Salisber Münasebat-1 İlhan ve Altın Ordu (Ordu-yı Zerrin)”, Mutala'at Tarih-i Íslam, Y11 3, S. 9, Tabistan 1390, s. 49-70; Alirıza KerimîHüseyin Resulî, “Avamil Tuneş der Revabit-1 İlhanan ba Ordu-yı Zerrin”, Fasılname-i Tarih Revabıt-ı Haricî, Yıl 14, S. 54, Bahar 1392, s. 1-20; Ebü'l-Fadl Rızavî, "Revabıt-ı İlhanan ba HavaninDeșt-i Kıbçak”, Fasılname-i Tarih Revabıt-ı Haricî, Yıl 19, S.46, Bahar 1390, s. 537539; I. M. Mirgaleev, “The Golden Horde Policies Toward the Ilkhanate”, Zolotoordınskoe Obozrenie, C. 2, (2013), s. $217-227$.

${ }^{3}$ Berke devri hakkında geniş bir değerlendirme için şu çalışmalara bkz. Yaşar Bedirhan, Bozkırda İslam ’n Kılıcı Berke Han (1257-1266), Eğitim Yayınevi, Konya 2021; Fatih Bostanc1, Berke Han Dönemi Altın Orda Devleti Tarihi (1256-1266) (Siyaset-Kültür-Din), Efe Akademi Yayınları, İstanbul 2021.

${ }^{4}$ Reşî̉düddîn, Câmi'üt-tevârîh, tsh. Muhammed Rûșen ve Mustafa Mûsevî, C. I, Tahran 1373, s. 738-739; Muîneddîn Natanzî, Müntehab ettevarîh-i Mu'inî, nşr. Pervin İstahrî, Tahran 1383, s. 63; Mirhând, Ravzatü’s-safa fi sireti'l-enbiyâve’l-mülûk ve’l-hulefâ, nşr. Abbas Perviz, C. V, Tahran 1375, s. 267-268; Hândmîr, Habib-i siyer fi ahbarü’l-beşer, tsh. M. Debirsiyaki, C. III, Tahran 1362 , s. 101.

${ }^{5}$ Kiragos, Ermeni Kaynaklarında Türkler ve Moğollar, haz. Hasan Oktay, İstanbul 2007, s. 98; Mhithar, Vakayiname, nșr. M.Brosset, StPetersbourg 1869, s. 108.

${ }^{6}$ Reşî̉düddîn, age, C. II, s. 1044; Benâketî, Ravzatü'l-ulî el-elbâb fi tevarîhü'l-ekâbir ve'l-ensab, Tarih-i Benâketî, nșr. Ca'ferŞi'ar, Tahran 1348 hş, s. 424; Mirhând, age, C. V, s. 267-268.

${ }^{7}$ Reşîdüddîn, age, C. II, s. 1044; Mirhând, age, C. V, s. 228; Hândmîr, age, C. III, s. 101

${ }^{8}$ Karatây el-'İzzî, Tarih mecmu' el-nevadir, thk. H.Hayn-M.Hacirî, Beyrut 2005, s. 126.
} 


\section{İLK DÖNEM ILLHANLI-ALTIN ORDA REKABETININ SEBEPLERİ HAKKINDA BİR DEĞERLENDİRME}

teferruatına girileceği üzere bunu takip eden ve iki taraf arasındaki gerilimi daha da artıracak bir dizi siyasî ve ekonomik gelişme de ilişkileri bir daha düzeltemeyecek ölçüde kopma seviyesine getirmiştir.

$\mathrm{Bu}$ çerçevede zikredilen hadiselerin, elbette husumetin sebepleri arasında olsa da mücadelenin tüm seyrine mal edilecek türden önemli bir etken olmadığını tahmin edebiliriz. Şayet mesele mezkûr hadiseden ibaret değil ise o vakit dikkati iki devlet arasındaki sınırlara çevirerek meselenin çözümündeki ipuçlarını buralarda aramak daha doğru olacaktır. Memlûk müelliflerinden el-Ömerî, İlhanlı hükümdarı Ebü Said'in kâtibi Nizameddin Ebü'l-Fadaîl Yahya b. Hakim Nureddin Abdurrahman el-Tayyarî'den naklettiğine göre, Han'ın (Mönge) Hülegü'yü başta İsmailîleri ve Kürtleri kovmak için gönderdiğini, Bağdat'ı aldıktan sonra da geri dönmeyerek buraları zapt ettiğini yazar. ${ }^{9}$ Esasında bu iddianın Reşîdüddîn tarafından da desteklendiği görülmektedir. Nitekim Reşîdüddîn, Mönge Han'ın Hülegü'yü batıya doğru yönlendirirken Cengiz Han'ın yasa ve yosununun kaidelerini büyük ve küçük işlerde uygulayarak Amuderya'dan (Ceyhun) Mısır beldelerine kadar yaymasını, Horasan'ın Kuhistan'dan başlayarak kalelerini ve hisarlarını yıkmasını, ardından Irak'a yönelerek burada taşkınlık yapan Kürt ve Lurları ezdikten sonra Bağdat halifesinin itaate mecbur bırakılmasını istediğini bildirir. Ayrıca Halife'nin mukavemet göstermesi durumunda Bağdat'ı almasını ve ardından büyük ordularla İran memleketinde hükümdar olarak kalmasını, fakat bu işleri yerine getirdikten sonra da asıl ordugâhına dönmesini buyurduğunu kaydeder. ${ }^{10}$ Burada açık bir şekilde, söz konusu seferin kalıcı olarak Hülegü’nün bölgeye yerleşmesi için yapılmadı̆̆ı görülmekte ve Hülegü'nün Büyük Moğol İmparatorluğu'nun batı topraklarını yönetmekle görevlendirildiği anlaşılmaktadır.

El-Ömerî, eserinin ileriki sayfalarında Hülegü’nün batıya doğru hareket ettiği sırada, Büyük Moğol İmparatorluğu ordusuna mensup her dört askerden birinin onun emrine verildiğinden bahseder. Fakat askerlerin görevlerini tamamlamasının ardından geri dönmediklerini, Hülegü tarafindan ele geçirilen eyaletlerin bu askerler arasında taksim edildiğini, Tebriz ve Meraga'yı da Deşt-i Kıpçak ve Harezm'den gelen ordulara verdiğini yazmaktadır. ${ }^{11} \mathrm{Bu}$ konuda sözüne çoğu kez itibar edilen Vassâf ise İlhanlı-Altın Orda arasındaki husumetin sebebini Cüveynî̀yi esas alarak Cengiz Han'ın devletini oğulları arasında taksimi meselesiyle ilişkilendirerek daha makul sebepler sayar. Müellif, Berke'nin Arran ve Azerbaycan’ı kendi mülkü saydığını ve Berke ile Hülegü arasındaki düşmanlık ateşinin bu sebepten ortaya çıktığını kaydeder. ${ }^{12}$ Karatây el- '̇̇zzî ve İbn Kesir gibi diğer Memlûk kaynakları, Hülegü ile Berke arasındaki düş̧manlığın sebebi olarak Bağdat'ta ele geçirilen ganimetin Cengiz Yasası'na göre İlhanlılar ve Altın Orda arasında pay edilmemiş olmasını kaydederek bu hususta Vassâf’a yaklaşırlar. ${ }^{13}$ Gerçekte de Cengiz Han, ölmeden önce toprakları oğulları arasında bölüştürmüş ve Kîyâlık, Harzem, Saksın, Bulgâr, Bakû geçidine kadarki sahalar büyük oğlu Cuci'nin hissesine düşmüştü. Bu sebeple Altın Orda Devleti de söz konusu yerler üzerinde meşru haklara sahip oluyordu. Marco Polo da Hülegü ve Berke arasındaki anlaşmazlığın sebebini sınır anlaşmazlığı olarak belirtir. ${ }^{14}$ Öyle anlaşılıyor ki Cengiz Han devrinde yapılan bu taksimat sırasındaki sınırlar daha sonra İlhanlıların sınırları içerisinde kalmıştır. İşin ilginç tarafı ise Batu devrinde başlayan bu süreçte Altın Orda Devleti buna karşı çıkmazken Berke devrine gelindiğinde ise buna tepki gösterilmesidir.

Memlûk kaynaklarına gelirsek, genellikle Hülegü ile Berke arasındaki düşmanlığın sebebi olarak din faktörü işaret edilmektedir. ${ }^{15}$ Nitekim Zehebî’nin anlattıklarına göre Müslümanlığı kabul eden Berke, Hülegü'nün Bağdat’ta yaptığı katliama son derece hiddetlenmiş̦i. Memlûk Sultanı Baybars da Hülegü'nün İslam'a verdiği zarardan dolayı gelen giden elçiler vasıtasıyla Berke'yi kendisine karşı kışkırtmıştı. ${ }^{16}$ Ebü Şame, Yunînî ve Ebü’l-Fedâil'e göre ise savaşın asıl sebebi Kubilây ile Arık Boğa arasındaki “Kağanlık” mücadelesidir. Nitekim müelliflere göre Berke'nin desteği ile Arık Boğa'nın Kubilây'ı yenmesi Hülegü’nün pek zoruna gitmişti. ${ }^{17}$ Fakat İbn Şeddâd'ın kayıp cildinden geniş iktibaslarda bulunan son iki müellifin aktardıkları başka bir kayıt sayesinde iki devlet arasındaki husumetin daha gerçekçi sebeplerine tesadüf edilebilmektedir. Nitekim İbn Şeddâd, Devaddar Seyfeddin Balbân el-Rumî’nin adamlarından Alâeddin b. Abdullah el-Bağdatî’den öğrendiği bir rivayete göre, 660/1261 yılında Berke; Balâgyâ ve Tatarşâ adında iki elçiyi Hülegü’ye göndermişti. Buna göre Berke, daha önce âdet olduğu üzere, fethedilen yerlerin vergilerinden kendi payına düsşeni istemişti. Moğol âdetine göre Ceyhun'un batısındaki yerler fethedildikten sonra ele geçirilen yerlerin gelirlerinin beşte birinin

\footnotetext{
${ }^{9}$ El-Ömerî, Mesalik, Mesâlikü’l-ebsâr fî memâlikü’l-emsâr, thk. K.S. el-Caburit, C. III, Beyrut 2010, s. 92.

${ }^{10}$ Reșîdüddîn, age, C. II, s. 976-977.

${ }^{11}$ El-Ömerî, age, C. III, s. 153-154.

${ }^{12}$ Vassâf, Tarih-i Vassâf, C. I, Bombay 1269, s. 50; Tahrir-i Vassâf, tsh. Abdu'l-Muhammed Âyeti, Tahran 1346, s. 27-28.

${ }^{13}$ Karatây el-‘İzzî, age, s. 126; İbnü'l-Kesir, el-Bidaye ve’n-nihaye, çev. Mehmet Keskin, C. XIII, İstanbul 1995 , s. 410.

${ }^{14}$ Marco Polo, Marko Polo Seyahatnamesi, çev. Filiz Dokuman, C. II, İstanbul 1979, s. 221.

15 İlhanl1-Altın Orda ilișkilerinde din faktörü hakkında bkz. Bergarî-Muhammedî, agm, s. 153-172; Mustafa Akkuş, “Altın Orda-İlhanlı İlişkilerinde Dinin Rolü’, Turkish Studies, S. 11, (Summer 2016), s. 1-12.

${ }^{16}$ Zehebî, el- 'İber fi haber men gaber, nşr. Muhammed Zaglul, C. III, Beyrut 1985, s. 301.

${ }^{17}$ Ebü Şame, Zeyl er-Ravzateyn, nşr. Abdülaziz el-Attar el-Hüseyni, Beyrut 1974, s. 220; Yûnînî, Zeyl miratü’z-zaman, C. I, Haydarabad 1955, s. 497-498; Ebü'l-Fedaîl, Nehcü's-sedîd ve'd-dürrü'l-ferîd fî mâba'de Târîhi İbni'l-Amîd, trans. E. Blochet, C. I, London 1910, s. 100102.
} 


\section{İBRAHIM GÜNEŞ}

Batu’nun ailesine, iki kısmının Mönge Han’a ve geri kalan son iki kısmının da askerlere dağıtılması gerekiyordu. Fakat Hülegü, Batu ölüp yerine Berke geçince hak edilen hâsılatı göndermemişti. ${ }^{18}$ Bunun üzerine Berke de Hülegü’ye içlerinde büyücülerin olduğu bir elçilik heyeti yollamıştı. Ardından bu büyücüler Hülegü tarafından Tela Kalesi'ne hapsedilmişler, ardından elçilerle birlikte topluca öldürülmüşlerdi. İște müellifin iddiası da bu vakadan sonra Berke’nin Hülegü’ye karşı düşmanlık beslemeye başladığı yönündedir. ${ }^{19}$

Kaynakların mezkûr nakilleri sayesinde iki devlet arasındaki husumetin asıl sebebinin tamamı ile çıkar meselesi olduğu anlaşılmaktadır. Filhakika Rus toprakları ile birlikte Kafkasya toprakları Cengiz Han'ın yaptığ taksimat sırasında Altın Orda Devleti'nin kurucusu sayılan Çuçi'nin hissesine düşmüştü. Lakin Göyük zamanından itibaren Kafkas topraklarında Altın Orda Devleti aleyhinde birtakım atamalar yapılıp, söz konusu devletin Kür Nehri'nin kuzey hattında tutulmasının amaçlandığı görülmektedir. Ayrıca tarihî İpek Yolu'nun en önemli güzergâhları İlhanlı topraklarından geçmekteydi. Özellikle Çin ve Hindistan'dan gelen her türlü mal Tebriz'e gelir, buradan da Erzurum-Erzincan-Sivas-Ayas üzerinden güneye iner ve henüz Tebriz'de iken Kafkaslar üzerinden Sudak'a çıkılır veya Trabzon üzerinden Konstantinapolis'e getirtilerek Avrupa'ya taşınırdı. İlhanlılar da bundan büyük bir kazanç sağlamaktaydı. Bu da söz konusu ticari güzergâhların Azerbaycan ve Kafkas ayağını elinde tutmak isteyen her iki devlet için yeni bir çatışma alanı yaratmaktaydı. ${ }^{20}$ Ayrıca kaynaklar, sınır çatışmalarını bu gerilimin en büyük sebebi olarak gösterse de o dönemde Moğol devletleri arasındaki kutuplaşmaların burada daha etkili bir faktör olduğu görülmektedir. Nitekim Kubilây üzerinde bir baskıya sebep olan Altın Orda'nın Büyük Moğol İmparatorluğu tarafından Rus topraklarına sıkıştırılıp Asya siyasetinin dışına atılmak istenmesinde İlhanlılara önemli görevler düştüğü anlaşılmaktadır.

\section{2. İlhanlı-Altın Orda Düşmanlığına Azerbaycan Bölgesinin Etkisi}

Batu’nun 655/1256 yılında ölmesiyle yerine geçen ve Müslümanlığı kabul etmiş olan Berke devrinde, İlhanlılar ile Altın Orda Devleti arasında yukarıda sayılan nedenler yüzünden bir husumet meydana gelmiştir. Bununla birlikte Azerbaycan topraklarında her iki taraf arasındaki sınırlar kesin olarak belirlenemediğinden, husumet kısa süre içerisinde yerini savaşlara bırakmıştır. Buradaki yegâne amaç ise yukarıda da gösterildiği üzere Azerbaycan'ın kime ait olduğu meselesiydi. ${ }^{21}$ Bunda Berke'nin açıktan açığa Kubilây'a karşı Arık Boğa'yı desteklemiş olması da etkili olmuşa benziyor. Nitekim Kubilây ile Berke'nin birbirlerine cephe almaları ve Kubilây’ı destekleyen Hülegü’nün Kafkasya topraklarında kendi devlet sınırlarını Kür Nehri olarak belirlemiş olması, İlhanlılar ile Altın Orda arasında yeni bir gerginliğe sebebiyet vermiştir. Öyle ki Altın Orda’nın Azerbaycan toprakları üzerindeki istekleri bilinen bir keyfiyet olmasına rağmen, Hülegü Meraga'yı kendine üs olarak seçmiştir. Abâkâ'nın Tebriz’i başkent olarak seçmiş olmasını da İlhanlıların Altın Orda'nın Azerbaycan üzerinde hak iddia etmesine karşı yapılmış bir önlem olarak görmek gerekir.

Azerbaycan ve Kafkasya’da bulunan ve özellikle yaz-kış adeta ot stoku işlevi gören zengin meralar, Moğollar gibi atlı muharip güçler üzerinden tanzim edilen ordular için hayati öneme sahipti. Bölge, bu sebeple bir hayli stratejik bir rol üsteleniyordu. Henüz batıya doğru ilk akınlar sırasında Moğol komutanlarının Azerbaycan mülhakatında bulunan Mugan'ı kendilerine üs olarak seçmeleri de yine bu zengin meralar ile ilgili olmalıydı. Gürcistan'dan başlayıp İran'ın kuzeybatı bölgelerine dek uzanan geniş platolar, doğal bir set görevi görürken, zengin meralar da askerlerin binekleri için önemli bir kaynak teşkil ediyordu. Bu sebeple olacak ki Hülegü ve halefi Abâkâ, Berke'nin ardı arkası kesilmeyen bölgeyi boşaltma talebini her defasında kulak arkası ediyor ve Altın Orda'nın tüm askerî kuvvetine rağmen bu amaçtan hiçbir suretle geri adım atmıyorlardı. Buradaki esas amacı Altın Orda Devleti'nin Azerbaycan ve Kafkaslar üzerindeki emellerinin önüne geçmek için yapılmış bir hamle olarak görmek gerekir. Ardından Abâkâ'nın tahta çıkmasına müteakip olarak Tebriz’i başkent hâline getirmesi de her açıdan babasının siyasetini tekmil etmesinden başka bir şey olmasa gerekir. Bununla birlikte Berke ve ardıllarının bu emellerini gerçekleştirmek üzere her firsatta saldırıya geçmelerine rağmen İlhanlılar tarafından oluşturulan bu savunma bloğunu aşamadıkları görülmektedir.

İlhanlı kaynaklarından Vassâf, 1263 yılındaki Terek Nehri Savaşı’ndan sonra Hülegü’nün ülkesine gelmesiyle Tebriz'de bulunan Berke'ye ait tacirlerin sayısız mallarına el koyarak onları öldürttüğünü, Altın Orda hükümdarının da aynı suretle buna karşılık vererek İlhanlı tacirlerini öldürtmesi sonucu tüccarın geliş gidişlerinin birden bire kesildiğini yazar. ${ }^{22}$ Şayet bu bilgi doğru kabul edilip, daha önce zikredilen sebeplere

\footnotetext{
${ }^{18}$ Kutbeddin Şirazî, Ahbar-ı Moğolân (650-683). Der inbâne’ Mollâ Kutb: ez mecmê-i hattı müverrih 685, nşr. İrec Afşar, Kum 1389, s. 40. ${ }^{19}$ Yûnînî, age, C. I, s. 497-498; Ebü'l-Fedaîl, age, C. I, s. 102-104.

${ }^{20} \mathrm{Bu}$ husus ile ilgili bkz. Virgil Ciociltan, The Mongols and the Black Sea Trade in the Thirteenth and Fourteenth Centuries, trans. Samuel Willcocks, Leiden-Boston 2012, s. 2-58.

${ }^{21}$ Cüzcanî, Berke Han'ı anlatırken Kıpçak, Saksın, Bulgar, Saklab ve kuzeydoğu Rum'a, Cend ve Harezm'e kadarki sahaların onun hükmüne girdiğini; Mönge Han'ın ölümünden sonra ise tüm doğu ve batı şehirleri olmak üzere, Acem, Mâverâünnehr ve Horasan memleketlerinde hutbenin onun adına okunmaya başlandığını yazmaktadır. Bkz. Cüzcanî, Tabakât-ı Nâsırî, çev. Mustafa Uyar, Ötüken Neşriyat, İstanbul 2016, s. 186.

${ }^{22}$ Vassâf, age, I, s. 50-51; Tahrir-i Vassâf, s. 28.
} 


\section{İLK DÖNEM ILLHANLI-ALTIN ORDA REKABETININ SEBEPLERİ HAKKINDA BİR DEĞERLENDİRME}

eklenirse iki taraf arasındaki derin bir düşmanlık için yeterli sebebin ortaya çıktığı herhalde kendiliğinden anlaşılacaktır.

Başından itibaren aralarında daima büyük bir husumetin var olduğu İlhanl-Altın Orda ilişkilerindeki seyrin Hülegü ve Abâkâ devrindeki olaylarla vücut bulduğu görülmektedir. Bunun aslında tamamıyla çıkar meselesi ile ilişkili olduğu anlaşılmaktadır. Abâkâ devrindeki İlhanlı ve Altın Orda ilişkileri de bu çerçevede bir tarihî seyir izlemişti. Fakat Abâkâ'nın hükümdarlı̆̆ının ilk yıllarında, geçmişteki hadiseleri unutup Altın Orda Devleti ile iyi ilişkiler kurmak istediği de bilinmektedir. El-Ömerî’ye göre Abâkâ’nın tahta geçmesinin akabinde Altın Orda hükümdarı kendisine haber göndererek Tebriz'de bir cami yaptırmak istemiştir. İlhanlı hükümdarı da buna rıza göstermiştir. Ardından Berke, yine aynı şekilde Tebriz'de kendi adına bir kumaş fabrikası kurmak istemiş, bu istek de Abâkâ tarafindan kabul edilmiştir. Fakat Abâkâ, Berke ile yaptığı 665/1266 y1lındaki savaşın dönüşünde bu cami ile birlikte fabrikayı yaktırmıștır. El-Ömerî, ileride iki hükümdar arasında barıș akdedilince cami ve fabrikanın tekrar inşa edildiğini yazar. ${ }^{23}$ Yukarıda nakledilen kayıtları doğru kabul etsek bile Abâkâ'nın bunu Mönge Timûr zamanında yapmış olması icap eder. Nitekim 665/1266 yılındaki savaş sırasında Berke’nin öldüğü bilinmektedir. Öte yandan varılan anlaşmaya göre Altın Orda halkı ticaret için paraları kendi ülkelerinden getirecekleri hususunda bir madde koydurmuşlardır. Müellifin iddiası da bu gelişme ile Altın Orda'nın Tebriz ve Meraga üzerinde hak iddia ettikleri yönündedir. Hatta müellif, bu talebin Gazan devrinde de devam ettiğini, bu suretle Altın Orda hükümdarı tarafindan bir elçi göndererek bu toprakların atalarının askerleri tarafindan fethedildiğini, dolayısıyla buraların kendi hakkı olduğundan kendilerine miras kaldığını ve kendilerine vermeleri gerektiği şeklinde bir talepte bulunduklarını yazar. Gazan da kendisine sert bir mukabelede bulunarak Tebriz ve Meraga'nın kendi malı olduğunu ve buraları kılıç ile elinde tuttuğunu belirtmişti. El-Ömerî, bu talebin kendi devrinde devam ettiğini ve Altın Orda hükümdarı Özbek'in (1313-1340) bu isteği her firsatta tekrar ettiğini ilave etmektedir. ${ }^{24}$

Altın Orda'nın İlhanlılara karşı saldırgan bir politika izlemesi, güneyde Memlûklerin de dikkatini çekmiştir. Bu sebeple Memlûk Sultanı Baybars, İlhanlılara karşı Berke'yi kendi tarafına çekmeye çalışmış ve bunda da muvaffak olmuştur. Nitekim İlhanlılara karşı Altın Orda ve Memlûkler arasında uzun süreli bir ittifak yapıldığı bilinmektedir. ${ }^{25}$ Hülegü’ye karşı beslediği düşmanlık sırasında güneyden gelen Memlûk ittifak teklifi Berke'ye aradığı desteği bulma firsatını vermiş, bu münasebetle de ilk Memlûk elçilik heyetinin ittifak önerisini derhal kabul etmiştir. Sultan Baybars'ın tahta geçmesinin ardından ilk olarak 659/1261 tarihinde Berke’ye bir elçi yollanmıştı. Fakat bu elçilik heyetinin umulanın aksine Altın Orda hükümdarı tarafından sıcak karşılanması üzerine ${ }^{26}$ 661/1262 y1lında Fakih Mecmeddin ve Seyfeddin Keşerbek'in başında olduğu ikinci bir elçilik heyeti görevlendirilmiștir. Bu elçilik heyeti de aynı suretle Berke tarafından gayet sıcak karşılanmıștır. Altın Orda hükümdarı daha sonra cevabi mektupla kendi elçilerini göndermiştir (11 Recep 661/2 Mayıs 1263). ${ }^{27}$ Memlûk kaynakları, bu minvalde Sultan Baybars'ın açık bir şekilde Berke'yi İlhanlılara karşı savaşmaya teşvik ettiğini yazarlar. Ardından başlayan elçi trafiği o kadar yoğunlaşmış̦tır ki kaynaklar bu tarihten itibaren sık sık bu elçilerin geliş ve gidişlerine yer verirler. Berke, Terek Nehri Savaşı'nda kazandığı zaferle ilgili Sultan Baybars'a haber göndermiştir. Sultan Baybars da onunla olan dostluğunun göstergesi olarak hutbelerde kendi adıyla beraber Berke'nin de ismini zikretmiștir. Ayrıca Hülegü'nün 667/1258 yılındaki Bağdat Seferi sırasında İlhanlılara destek veren Altın Orda askerleri 660/1262 yılında Memlûk sultanına sığınıp ülkesine iltica talep etmişlerdi. Kaynaklar bunların başında Kermun Aka'nın olduğunu ve sayılarının da yaklaşık bin üç yüz olduğunu yazarlar. Sultan Baybars, bu iltica tekliflerini gayet sıcak bir şekilde kabul etmişti. ${ }^{28}$ Fakat Berke'nin Müslüman oluşu sebebiyle Memlûk-Altın Orda dostluğu, görünüşte aynı dinden zuhur etmiş bir cihat düşüncesi olarak telakki edilmesi doğru değildir. Bu da olsa olsa ortak düşmana, yani İlhanlılara karşı olan siyasetlerini pekiştirmek için oluşan bir zaruretten başka bir şey olmasa gerekir. Söz konusu "bloklaşma"nın da dışarıdan bakıldığında her taraftan tarihin akışına uygun olarak sadece "çıkar" ittifakından başka bir şey olmadığı anlaşılmaktadır.

\footnotetext{
${ }^{23}$ El-Ömerî, age, C. III, s. 153-154.

${ }^{24}$ El-Ömerî, age, C. III, s. 153-154.

${ }^{25}$ Bu husus ile ilgili bkz. Marie Favereau, “The Golden Horde and the Mamluks”, Golden Horde Review, C. 5, S. 1, (2017), s. 93-115; Yunus Ferahmand-Kadriye Tacbahş, "Berke Han ve Baybars: Tasir 'Avasıl Dini-İktisadi ber Ta'mik Revabit-1 Ticari Altın Ordu ve Memalik-i Bahri Misır”, Fasilname-i ‘İlmi, Y11 20, S. 83, (Bahar 1389), s. 85-101.

${ }^{26}$ İbn Abdüzzâhir, Ravzü'z-zâhir fî sîretü'l-Melikü'z-Zâhir, nşr. Abdülaziz el-Huveytır, Riyad 1976, s. 88-89.

${ }^{27}$ İbn Abdüzzâhir, age, s. 137-140.

${ }^{28}$ İbn Abdüzzâhir, age, s. 170-174, 178-180, 202-203, 209-210, 218; İbn Vâsıl, Müferricü’l-kurub ahbar-ı Beni Eyyûb, nşr. Ö. A.Tedmurî, C. VI, Beyrut 2004, s. 340-341, 348-350, 378-381; Yûnînî, age, C. I, s. 533-534, 538-541; Baybars el-Mansurî, Zübdetü’l-Fikre f î Tarih elHicre, thk. D. S. Richards, Beyrut 1998, s. 84-85; Zehebî, Târîhü'l-IIslâm ve vefeyât el-meșâhîr ve el-a'lâm, thk. Ömer Abdüsselam Tedmuri, C. XL, Beyrut 1997, s. 8; Ebü'l-Fedaîl, I, s. 452-462; İbnü'l-Devâdârî, Kenzü'd-dürer ve câmi'ü'l-gurer: ed-dürre'l-fâhir fî sîretü’l-Melik en-Nâsir, nşr. Hans Robert Roemer, C. VIII, Kahire 1960, s. 97-101; el-Aynî, İkdü'l-cümân fî târîhi ehlü'z-zamân, nşr. Muhammed M. Emin, C. I, Kahire 1987, s. 333, 360-363.
} 


\section{İBRAHIM GÜNEŞ}

Berke, Hülegü’nün ölümü üzerine yerine geçen Abâkâ’nın genç ve tecrübesiz olduğunu hesap etmiş olmalı ki bu münasebetle 1266 yılında İlhanlı Devleti'ne saldırmış, fakat Altın Orda hükümdarının sefer sırasında ölmesi üzerine iki taraf arasında ciddi bir savaş yaşanmamıştır. Berke’nin ölümünden sonra yerine geçen Mönge Timûr devrinde de bu düşmanca siyasete devam edilmiştir. ${ }^{29}$ Öyle ki İbn Abdüzzâhir'in kaydettiklerinden anlaşıldığı üzere, Sultan Baybars'ın Altın Orda hükümdarına Safer 666/Kasım 1267 tarihinde bir elçi heyetini göndermesi ve Mönge Timûr'un buna cevap olarak aynı istekleri bildiren bir elçi heyetini yola çıkartması da bunu desteklemektedir. Ardından Mönge Timûr, 668/1269 yılında Sultan Baybars'a yeni bir elçilik heyeti göndermiştir. Bu münasebetle eski dostluklarını devam ettirmek istediklerini ve onlarla düşmanlarını bir tuttuklarını söyleyerek İlhanlılara karşı mücadeleye sıcak baktığını göstermiştir. ${ }^{30}$ Fakat ardından Altın Orda hükümdarı, Kubilây'ın isteği ile İlhanlılarla zoraki bir barış antlaşması imzalamıştır. Bu sebeple umduğunu bulamayan Sultan Baybars’a yeni bir elçilik heyeti göndermişse de iki taraf arasındaki ilişsilerin İlhanlılara karşı fiilî bir ittifaka dönüşmediği görülmektedir. ${ }^{31}$

Öte yandan Mönge Timûr'un Berke'nin siyasetini devam ettirmesi ve İlhanlılar ile savaşması neticesinde Abâkâ’nın da yeni bir siyasete yöneldiği görülmektedir. Esasında Abâkâ'nın Altın Orda'nın iç işlerine hiçbir suretle karışmak istememesine rağmen, Mönge Timûr'un karşısına rakip olarak çıkan Nogay'a yaklaşmakta bir sakınca görmemiştir. Ayrıca bir kızını Nogay'ın oğlu Börü’ye vererek onu kendi tarafına çekmeye çalışmıştır. İlhanlılar ile Altın Orda arasında kutuplaşmanın iyice arttığı bir dönemde Kubilây'ın baskısı ile Abâkâ ve Mönge Timûr, 669/1270 yılında kendi aralarında bir barış antlaşması imzalamışlardır. ${ }^{32}$ Ardından da Abâkâ ile Mönge Timûr arasında dostluk amaçlı birtakım elçilerin gelip gittiği anlaşılmaktadır. Nitekim Reşîuüddîn, 671/1272 tarihinde Mönge Timûr tarafindan Barâk'a karşı zaferini kutlamak için elçiler geldiğini ve elçilerin bu sırada içinde doğan, sungur ve şahinlerin de olduğu çeşitli hediyelerle Abâkâ'nın huzuruna çıtıklarını kaydeder. ${ }^{33}$ Neticede İlhanlı hükümdarı bu elçileri bir hayli sıcak karşılayarak muhtelif izzet ve ikramlarla onları taltif etmiştir. Ardından Mönge Timûr'a yolladığı hediyelere karşılık olarak da birçok değerli hediye hazırlatarak kendisine göndermiştir. ${ }^{34}$

İlhanlılar ile Altın Orda arasında imzalanan anlaşma, sadece kâğıt üzerinde kalan ve fazla bağlayıcıllı̆g olmayan bir metin olarak kalmaya devam etmiştir. Nitekim Memlûk kaynaklarına göre Mönge Timûr yapılan anlaşmaya aykırı olarak 672/1273 tarihinde Abâkâ'ya karşı yardım istemek üzere Arapça ve Farsça yazılmış olan bir mektubu, yeni bir elçilik heyetiyle birlikte Mısır’a yollamıştır. Fakat bu elçilik heyeti, yolda Haçlılar tarafindan alıkonulmuş, Sultan Baybars'ın girişimleri neticesinde serbest bırakılmıştır. Baybars el-Mansûrî, Hıms savaşından sonra Mönge Timûr'un Sultan Kalavûn'a elçi yolladığından bahseder. ${ }^{35}$ Lakin söz konusu kayıtların Abâkâ'ya karşı istediği yardımı Altın Orda hükümdarlarında bulamayan Memlûk cephesinde yazıldığından, bunlara bazen ihtiyatla yaklaşmak gerekir.

\section{SONUÇ}

Berke ile Hülegü zamanında yaşanan gerilim ve onu takip eden savaşlar, halefleri Abâkâ Han ve Mönge Timûr devrinde daha da şiddetlenmiş ve Altın Orda-i̇lhanlılar arasındaki düşmanlık, İlhanlıların çökmesine kadar devam etmiştir. İki taraf arasındaki mücadelelerde en büyük sebebin Azerbaycan ve Kafkas toprakları üzerinde hak iddiası olduğu görülmektedir. Bunda Cengiz Han devrindeki idari taksimatın etkisi bilinmektedir. Özellikle Azerbaycan ve Kafkasya’nın geniş meralara sahip olmasının, söz konusu düşmanlığın şiddetlenmesinde önemli bir faktör olduğu anlaşılmaktadır. Nitekim Azerbaycan ve Kafkasya'nın sahip olduğu geniş meralar ve av sahaları göçebe bir hayat sürmeyi tercih eden Moğollar için önem arz etmekteydi. Bu sebeple Berke, söz konusu toprakların Cengiz Han devrinde kendi hisselerine düştüğünü iddia ederek İlhanlıların bölgeyi boşaltmalarını istemiştir. Fakat buna cevap olarak Hülegü de ordusunun önemli bir kısmını Meraga ve Mugan'a yerleştirmek suretiyle bu konuda geri adım atmayacağını göstermiştir. Altın Orda Devleti, bu iddiadan hiçbir suretle vazgeçmeyerek birçok defa İlhanlılara saldırmıştır. Berke'nin Hülegü ve Abâkâ devrinde Kafkasya'yı işgal etmesi ve onun da ölümüyle yerine geçen Mönge Timûr'un aynı istekleri devam ettirmesi, kaçınılmaz olarak Altın Orda'yı İlhanlıların haricî en büyük tehdidi hâline getirmiştir. Fakat hem Hülegü hem de Abâkâ'nın Altın Orda saldırıları karşısında başarıı bir şekilde savaştıkları görülmektedir.

\footnotetext{
${ }^{29}$ Vassâf, age, C. IV, s. 580; Tahrir-i Vassâf, tsh. Abdu'l-Muhammed Âyeti, Tahran 1346, s. 332.

${ }^{30}$ İbn Abdüzzâhir, age, s. 334-335, 400; Baybars el-Mansûrî, age, s. 109.

${ }^{31}$ George Vernadsky, Moğollar ve Ruslar, çev. Eşref Bengi Özbilen, Selenge Yayınları, İstanbul 2007, s. 204.

${ }^{32}$ Vernadsky, age, s. 204.

${ }^{33}$ Reşîüddîn, age, C. II, s. 1097.

${ }^{34}$ Mîrhând, age, C. V, s. 308.

${ }^{35}$ Baybars el-Mansûrî, age, s. 209.
} 


\section{İLK DÖNEM İLHANLI-ALTIN ORDA REKABETININ SEBEPLERİ HAKKINDA BİR DEĞERLENDİRME}

\section{KAYNAKÇA}

ABBAS, Cevad-MUHAMMEDÎ, Meryem, "Te'sir Hükümethay-yı Salisber Münasebat-1 İlhan ve Altın Ordu (Ordu-y1 Zerrin)", Mutala'at Tarih-i İslam, Yıl 3, S. 9, Tabistan 1390, ss. 49-70.

AKKUŞ, Mustafa, “Altın Orda-İlhanlı İlişkilerinde Dinin Rolü”, TurkishStudies, S. 11, Summer 2016, ss. 1-12.

BAYBARS EL-MANSURÎ, Zübdetü’l-Fikre fî Tarih el-Hicre, thk. D. S. Richards, Beyrut 1998.

BEDİRHAN, Yaşar, Bozkırda İslam'ın Kılıcı Berke Han (1257-1266), Eğitim Yayınevi, Konya 2021.

BENÂKETÎ, Ravzatü'l-ulî el-elbâb fi tevarîhü'l-ekabirve’l-ensab, Tarih-i Benâketî, nşr. Ca'fer Şi'ar, Tahran 1348.

BOSTANCI, Fatih, Berke Han Dönemi Altın Orda Devleti Tarihi (1256-1266) (Siyaset-Kültür-Din), Efe Akademi Yayınları, İstanbul 2021.

CIOCILTAN, Virgil, The Mongols and the Black Sea Trade in the Thirteenth and Fourteenth Centuries, trans. Samuel Willcocks, Leiden-Boston 2012.

CÜZCANÎ, Tabakât-ı Nâsırî, çev. Mustafa Uyar, Ötüken Neşriyat, İstanbul 2016.

EBÜ ŞAME, Zeyl er-Ravzateyn, nşr. Abdülaziz el-Attar el-Hüseyni, Beyrut 1974.

EBÜ’L-FEDAîL, Nehcü's-sedîd ve'd-dürrü’l- ferîd fî mâba'de Târîhi İbni'l-Amîd, trans. E. Blochet, I, London 1910.

EL-AYNî, İkdü'l-cümân fî târîhi ehlü'z-zamân, nşr. Muhammed M. Emin, C. I, Kahire 1987.

EL-ÖMERÎ, Mesalik, Mesâlikü’l-ebsâr fî memâlikü'l-emsâr, thk. K.S.el-Caburi, C. III, Beyrut 2010.

FAVEREAU, Marie, “The Golden Horde and the Mamluks”, Golden Horde Review, S. 1, 2017, ss. 93-115.

FERAHMAND, Yunus-TACBAHŞ, Kadriye, "Berke Han ve Baybars: Tasir 'Avasıl Dini-İktisadi ber Ta'mik Revabit-1 Ticari Altın Ordu ve Memalik-i Bahri Mısır’, Fasılname-i ‘'ilmi, Yıl 20, S.83, Bahar 1389, ss. 85-101.

GÜNEŞ, İbrahim, Abâkâ Han Devrinde İlhanlı Devleti Tarihi (663-680/1265-1282), Muğla Üniversitesi Sosyal Bilimler Enstitüsü (Yayımlanmamış Doktora Tezi), Muğla 2021.

HÂNDMÎR, Habib-i siyer fi ahbarü'l-beşer, tsh. M. Debirsiyaki, C. I-III, Tahran 1362.

İBN ABDÜZZÂHİR, Ravzü’z-zâhir fî sîretü’l-Melikü’z-Zâhir, nşr. Abdülaziz el-Huveytır, Riyad 1976.

İBN VÂSIL, Müferricü'l-kurub ahbar-ı Beni Eyyûb, nşr. Ö.A.Tedmurî, C. VI, Beyrut 2004.

IBNÜ'D-DEVÂDÂRÎ, Kenzü'd-dürer ve câmi'ü'l-gurer: ed-dürre'l-fâhir fî sîretü'l-Melik en-Nâsır, nşr. Hans Robert Roemer, VIII, Kahire 1960.

İBNÜ'L-KESIR, el-Bidaye ve'n-nihaye, çev. Mehmet Keskin, C. XIII, İstanbul 1995.

KAFALI, Mustafa, Altın Orda Hanlı̆̆ının Kuruluşu ve Yükseliş Devirleri, İstanbul 1976.

KAMALOV, İlyas, Moğolların Kafkasya Politikası, Kaknüs Yayınevi, İstanbul 2003.

KARATÂY EL-‘'̇ZZÎ, Tarih mecmu’ el-nevadir, thk. H.Hayn-M.Hacirî, Beyrut 2005.

KERIMÎ, Alirıza-RESULÎ, Hüseyin, “Avamil Tuneş der Revabıt-ı İlhanan ba Ordu-yı Zerrin”, Fasılname-i Tarih Revabıt-ı Haricî, Yıl 14, S. 54, Bahar 1392, ss. 1-20.

KHELEJANI, Ahmad Hesamipour, Ilhanlılar ile Altın Orda Devleti'nin Siyasi ve Sosyal IIlişkileri, Ege Üniversitesi Sosyal Bilimler Enstitüsü (Yayınlammamış Doktora Tezi), İzmir 2013.

KİRAGOS, Ermeni Kaynaklarında Türkler ve Moğollar, Haz. Hasan Oktay, İstanbul 2007.

KUTBEDDIN şiRAZÎ, Ahbar-ı Moğolân (650-683). Der inbâne’ Mollâ Kutb: ez mecmê-i hattı müverrih 685, nşr. İrec Afşar, Kum 1389.

MARCO POLO, Marko Polo Seyahatnamesi, çev. Filiz Dokuman, C. I-II, İstanbul 1979.

MHITTHAR, Vakayiname, nşr. M. Brosset, St-Petersbourg 1869.

MiRGALEEV, I. M., “The Golden Horde Policies Toward the Ilkhanate”, Zolotoordinskoe Obozrenie, C. II, (2013), ss. 217-227 


\section{İBRAHIM GÜNEŞ}

MîRHÂND, Ravzatü's-safa fi sireti'l-enbiyâ ve'l-mülûk ve'l-hulefâ, nşr. Abbas Perviz, C. I-V, Tahran 1375.

MUHAMMEDÎ, Meryem, "Avamil Mu'ser der Revabit İran ve Ordu-yı Zerrin der Devre-i Zamamdarî Hûlâgû ve Abâkâ Han”, Pejuheşname-i Tarih, S. 4, Zemistan 1386, ss. 103-125.

MUÎNEDDÎN NATANZî, Müntehab et-tevarîh-i Mu'inî, nşr. Pervin İstahrî, Tahran 1383.

REŞîDÜDDÎN, Câmi’üt-tevârîh, tsh. Muhammed Rûşen ve Mustafa Mûsevît, I-IV, Tahran 1373.

RIZAVÎ, Ebü'l-Fadl, "Revabıt-1 İlhanan ba Havanin Deşt-i Kıbçak”, Fasılname-i Tarih Revabıt-ı Haricî, Yıl 19, S.46, Bahar 1390, ss. 537-539.

TAHRIR-I VASSÂF, tsh. Abdu'l-Muhammed Âyeti, Tahran 1346.

VASSÂF, Tarih-i Vassâf, C. I-V, Bombay 1269.

VERNADSKY, George, Moğollar ve Ruslar, çev. Eşref Bengi Özbilen, Selenge Yayınları, İstanbul 2007.

YÛNîNî, Zeyl miratü'z-zaman, C. I, Haydarabad 1955.

ZEHEBÎ, el-'íber fi haber men gaber, nşr. Muhammed Zaglul, C. I-III, Beyrut 1985.

ZEHEBÎ, Târîhü'l-İslâm ve vefeyât el-meşâhîr ve el-a'lâm, thk. Ömer Abdüsselam Tedmuri, C. XL, Beyrut 1997. 
İLK DÖNEM İLHANLI-ALTIN ORDA REKABETININ SEBEPLERİ HAKKINDA BİR DEĞERLENDİRME 